\title{
Patterns of Maxillofacial Fractures in Road Traffic Crashes in an Indian Rural Tertiary Center
}

\author{
${ }^{1}$ Rijo M Jayaraju, ${ }^{2}$ A Sagayaraj, ${ }^{3}$ Mallika P Reddy, ${ }^{4}$ KR Harshitha, ${ }^{5}$ Priyanka Majety
}

\begin{abstract}
Background and objectives: Road traffic crashes are reported to be the leading cause of maxillofacial fractures in developing countries. The large variability in reported incidence and etiology is due to a variety of contributing factors, including environmental, cultural and socioeconomic factors. The study aims at describing the patterns of maxillofacial fractures in road traffic crashes by clinical and radiological methods and to study the complications associated with these fractures.
\end{abstract}

Materials and methods: The study included 100 road traffic crash patients with maxillofacial injuries. Patients were evaluated for any maxillofacial fracture by clinical assessment and, radiologically, using plain radiographs and computed tomography scan.

Results: Midfacial skeleton was more prone to fractures. Isolated fractures of the maxilla was the commonest (58\%) followed by nasal bone fractures (43\%). Among the complex fractures, Le Fort type II was the commonest. Mandibular fractures were seen in $33 \%$ of the patients, parasymphysis being the commonest site. Majority of the patients had associated soft tissue injuries. The incidence of complications associated with maxillofacial fractures was $11 \%$, malocclusion being the commonest.

Conclusion: Maxillofacial fractures are commoner in the mobile population in the most productive age group, more so in two wheeler riders causing significant morbidity and mortality. Midface region is more prone to fractures and is most of the time associated with complications.

Keywords: Maxillofacial injuries, Road traffic crashes, Patterns of fracture, Complications.

How to cite this article: Jayaraju RM, Sagayaraj A, Reddy MP, Harshitha KR, Majety P. Patterns of Maxillofacial Fractures in

\footnotetext{
${ }^{1}$ Senior Resident, ${ }^{2}$ Associate Professor, ${ }^{3,4}$ Assistant Professor ${ }^{5}$ Intern

${ }^{1}$ Department of Otorhinolaryngology, Sapthagiri Institute of Medical Sciences and Research Center, Bengaluru, Karnataka India

${ }^{2,5}$ Department of Otorhinolaryngology, Sri Devaraj Urs Medical College, Kolar, Karnataka, India

${ }^{3,4}$ Department of Oral and Maxillofacial Surgery, Sri Devaraj Urs Medical College, Kolar, Karnataka, India
}

Corresponding Author: Rijo M Jayaraju, Senior Resident Department of Otorhinolaryngology, Sapthagiri Institute of Medical Sciences and Research Center, Bengaluru, Karnataka India, Phone: 8904677317, e-mail: rmangalasseril@gmail.com
Road Traffic Crashes in an Indian Rural Tertiary Center. Panam J Trauma Crit Care Emerg Surg 2014;3(2):53-58.

Source of support: Nil

Conflict of interest: None

\section{RESUMEN}

Antecedentes y objetivos: Los accidentes de tráfico son notificado a ser la principal causa de fracturas maxilofaciales en los países en desarrollo. La gran variabilidad en la incidencia y la etiología es debido a una variedad de factores que contribuyen, incluyendo factores ambientales, culturales y socioeconómicos. El estudio tiene como objetivo describir los patrones de fracturas maxilofaciales en carretera los accidentes de tráfico por métodos clínicos y radiológicos y estudiar las complicaciones asociadas a este tipo de fracturas.

Materiales y métodos: En el estudio participaron 100 carretera pacientes de accidentes de tráfico con lesiones maxilofaciales. Los pacientes fueron evaluada para cualquier fractura maxilofacial por la evaluación clínica y, radiológicamente, usando radiografías simples y computarizada tomografía.

Resultados: Esqueleto del tercio medio facial era más propensos a las fracturas. Las fracturas aisladas del maxilar fue el más común (58\%) seguido de fracturas óseas nasales (43\%). Entre el complejo fracturas, Le Fort tipo II fue la más común. Mandibular fracturas se observaron en el $33 \%$ de los pacientes, parasínfisis siendo el sitio más común. La mayoría de los pacientes tenía lesiones de tejidos blandos asociados. La incidencia de complicaciones asociado con las fracturas maxilofaciales fue de 11\%, la maloclusión siendo la más común.

Conclusión: Las fracturas maxilofaciales son más comunes en el población móvil en el grupo de edad más productiva, más aún en dos pilotos ruedas causan morbilidad y mortalidad significativas. Región media de la cara es más propenso a fracturas y es la mayor parte del tiempo asociado con complicaciones.

Palabras claves: Lesiones maxilofaciales, Colisiones de tránsito, Patterns de fractura, Complicaciones.

\section{INTRODUCTION}

Road traffic fatalities have been increasing at about $8 \%$ annually for the last 10 years and are the leading causes of morbidity and mortality across the world. ${ }^{1}$ Annually, over 1 million people die and over 25 million are injured or permanently disabled from road traffic injuries. The primary cause of maxillofacial fractures throughout the world is road traffic crashes. ${ }^{2}$ 
Motorcycle crash injuries constitute a disproportionate number of motor vehicle crash-related deaths and hospital admissions each year. Among the injuries caused by road traffic crashes, head injury can lead to morbidity and mortality as compared to other injuries and most of these have associated facial fractures. ${ }^{3}$

The incidence of maxillofacial fractures varies widely between different countries. The large variability in reported incidence and etiology is due to a variety of contributing factors, including environmental, cultural and socioeconomic factors. ${ }^{4}$

Management of facial fractures requires a multidisciplinary approach. Early intervention and appropriate treatment greatly reduces the morbidity associated with these fractures. ${ }^{5}$

\section{MATERIALS AND METHODS}

In this prospective hospital-based study, 100 patients with maxillofacial injuries following a road traffic crashes presenting to the emergency room and managed in the Department of Otorhinolaryngology and Oral and Maxillofacial surgery of RL Jalappa Hospital and Research Center, Kolar, Karnataka, from December 2011 to June 2013, were included in the study. Patients with previous history of maxillofacial injuries were excluded from the study. The study was approved by the institutional ethical committee.

Information relevant to the study was obtained from the patient directly or from the relatives attending to the patients. Clinical history was taken pertaining to symptoms of maxillofacial injuries. Altered bite, inability to open the mouth, double vision, nasal or oral bleed and paresthesia over the face. All patients then were thoroughly examined to rule out associated injuries. A detailed examination for any facial soft tissue injury, epistaxis and oral bleed were performed.

Facial skeletal framework was examined for any deformity, bony crepitus. Oral and nasal cavities were examined in detail and all positive findings were documented. All patients underwent radiographical evaluation by relevant plain radiographs: X-ray paranasal sinus (Water's view), $\mathrm{X}$-ray nasal bones (lateral view) and X-ray mandible (lateral oblique view). Seventy-six patients underwent comupted tomography (CT) scan of the head and face to study the patterns of maxillofacial fractures.

The fractures were assessed in seven regions: Frontal bone fractures, zygomatic bone fractures, nasal bone fractures, orbital fractures, maxillary fractures, mandibular fractures and complex fractures and ; Le Fort fractures. The anatomic locations of each of the fractures were studied in detail. Data collected were analyzed using SPSS 16.0 software.

\section{RESULTS}

The study constituted of 100 road traffic crash patients with documented maxillofacial fractures. Ninety-one patients were males and nine females with a male to female ratio of 9:1. Majority of the patients were young adults in the age group 21 to 30 years (45\%). The mean age was 32.08 years. The two-wheeler riders were the most commonly affected group ( 65 patients) followed by pillions (16 patients). Four patients were pedestrians who were hit by other vehicles and four were passengers in a public transport.

Forty-five patients presented with oral bleed and 75 with nasal bleed most of which stopped spontaneously. Seven patients required nasal packing to control the bleeding. The rest were managed conservatively. Ten patients had upper airway obstruction due to mandibular fracture and gross soft tissue edema for which tracheostomy had to be done. Most of our study population had associated soft-tissue injuries, commonest being facial edema/swelling in 71 patients, abrasions in 64 patients and lacerations of varying severity in 63 patients (Fig. 1).

Sixty-four percent of our patients sustained multiple facial fractures. Among the 100 patients studied, only 36 had isolated bone fractures. The commonest facial bone fractured was the maxilla (58\%), followed by nasal bone (Table 1).

Twenty-six patients had frontal bone fractures. Anterior table alone was fractured in 25 patients, bitable fracture in one patient. All the patients were managed conservatively for frontal sinus fractures. The patient with bitable fracture succumbed to a large intracranial hematoma in a few days. Forty-three percent of the patients had nasal bone fractures, which were classified into five types (Table 2). Type I nasal bone fracture was the commonest type.

Forty-one patients in our study had orbital wall fractures, and lateral orbital wall fracture was the commonest encountered fracture. One patient suffered globe rupture and

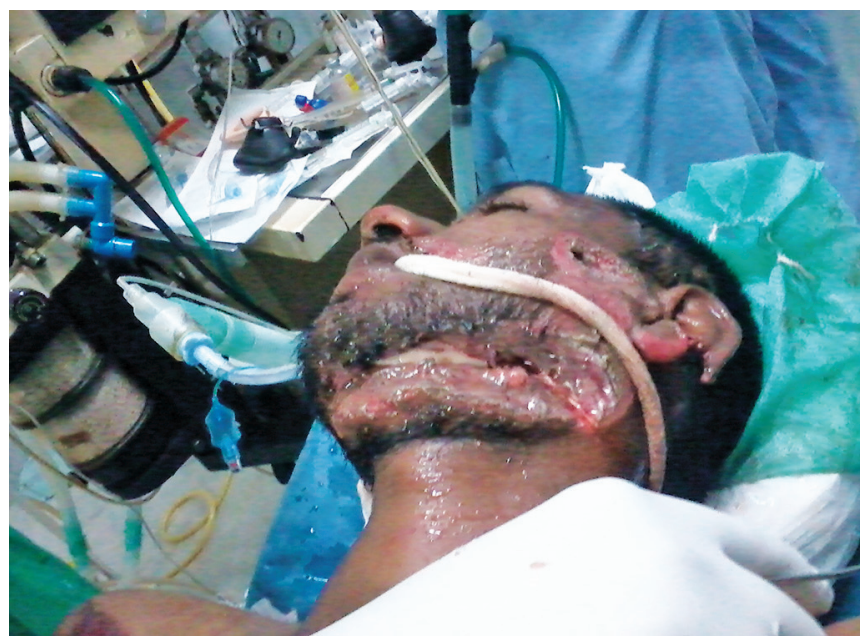

Fig. 1: Fracture of the mandible with extensive soft tissue injury 


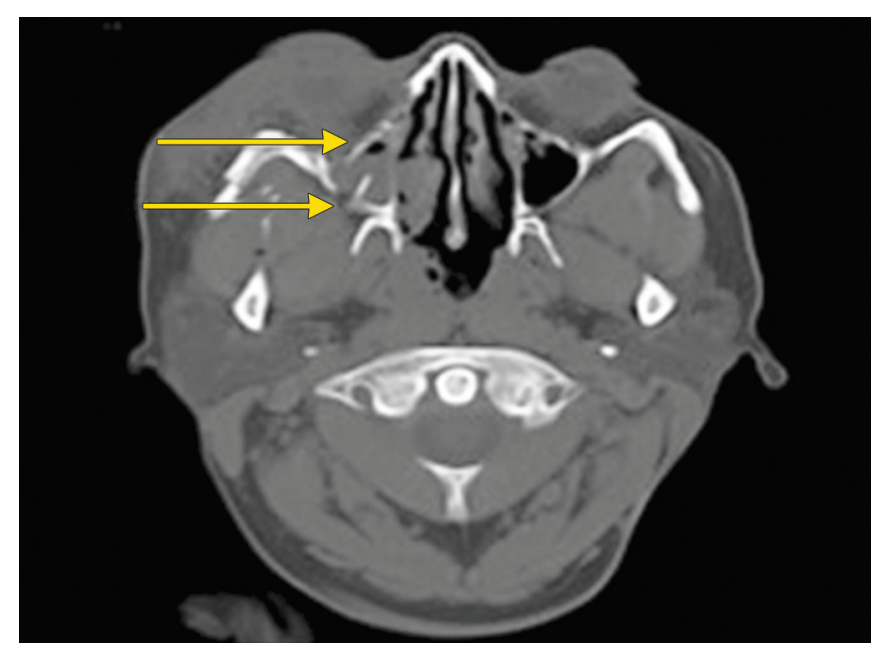

Fig. 2: Computed tomography scan showing fracture of anterior and posterior walls of maxilla (arrows marked)

underwent enucleation. Thirty-seven patients had a zygoma fracture. These included 23 fractures of the zygomatic arch and 12 fractures of the body of zygoma and combined fractures in two patients. The fractures were simple and undisplaced in 27 patients and displaced in 10 patients. One patient with zygoma fracture required open reduction and internal fixation.

Maxilla is the most commonly fractured facial bone in our study (58 patients). Among 58 patients, 45 patients suffered unilateral maxillary fracture and 13 had bilateral

Table 1: Pattern of facial fractures

\begin{tabular}{ll}
\hline Fracture & No. of patients \\
\hline Maxilla & 58 \\
Nasal bone & 43 \\
Orbit & 41 \\
Zygoma & 37 \\
Mandible & 33 \\
Frontal bone & 26 \\
Le Fort & 13 \\
\hline
\end{tabular}

Table 2: Pattern of nasal bone fractures

\begin{tabular}{lll}
\hline Types & Type of fracture & $n=43$ \\
\hline I & Simple straight & 21 \\
II & Simple deviated & 11 \\
III & Comminuted fracture of nasal bones & 9 \\
IV & Severely deviated nasal and septal fractures & 2 \\
V & Complex nasal and septal fractures & 0 \\
\hline
\end{tabular}

Table 3: Location of mandible fractures

\begin{tabular}{ll}
\hline Location of fracture & No. of cases \\
\hline Condyle & 3 \\
Subcondyle & 4 \\
Ramus & 2 \\
Angle & 3 \\
Body & 5 \\
Parasymphysis & 22 \\
Symphysis & 4 \\
\hline
\end{tabular}

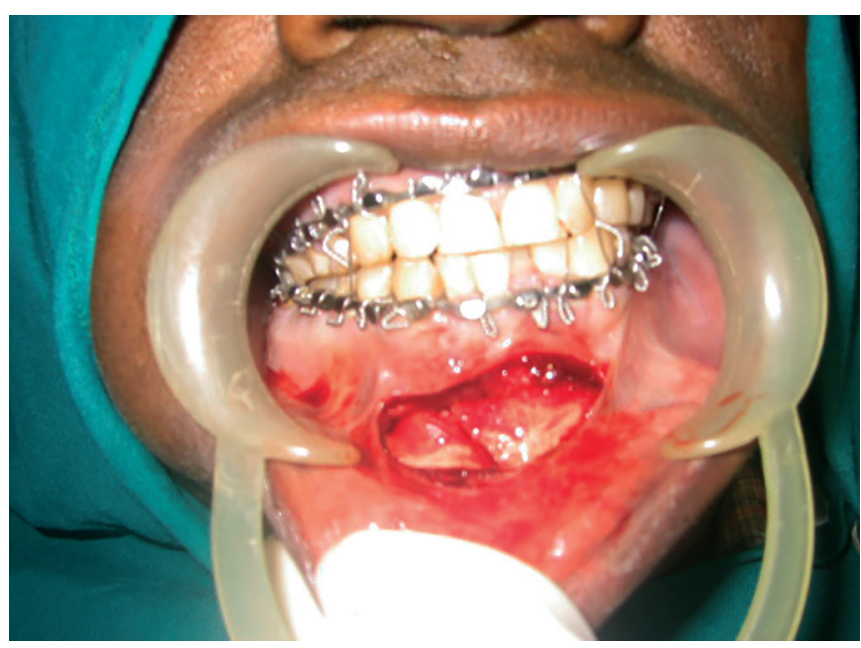

Fig. 3: Mandibular fracture being demonstrated preoperatively

fractures. Anterior wall of the maxilla was the commonest site of fracture (57 patients). Only 13 patients had a classical patterned Le Fort fracture. Type II Le Fort was the commonest fracture type encountered in our study. All 13 patients underwent open reduction and internal fixation with plate and screws (Fig. 2).

Thirty-three patients suffered mandibular fractures. A total of 43 fractures were documented (Table 3). Parasymphysis fractures were the commonest encountered (22 cases). All fractures of the mandible required open reduction and internal fixation with plate and screws.

Majority of the facial fractures were managed conservatively (48 patients). Eighteen patients underwent intermaxillary fixation (IMF) for temporary stabilization of fractures. Five patients with nasal bone fractures underwent closed reduction. Forty patients underwent open reduction and internal fixation with plate and screws, the indications of which were fracture mandible in 33 cases and midface fractures in the rest (Fig. 3).

Eleven patients in our study developed complications following maxillofacial trauma during the 3 months follow-up period (11\%). Malocclusion was the commonest complication seen in our study (8 patients). Seven of these patients had combined mandibular and maxillary fractures. One patient sustained a fracture of the mandible alone. Three patients underwent correction by open reduction and internal fixation, and five patients were lost to follow-up. Secondary wound infection was seen in four patients treated earlier by open reduction and internal fixation which was treated with antibiotics in accordance with the culture and sensitivity reports and all infections responded to treatment and were resolved within a week. Four patients had post-traumatic cerebrospinal fluid (CSF) rhinorrhea, three secondary to nasoethmoid fractures and one secondary to fracture of frontal sinus, two among them requiring an endoscopic repair. 


\section{DISCUSSION}

The pattern of maxillofacial injuries varies from one geographical area to another depending on the prevailing socioeconomic, cultural, geographic and environmental factors. Road traffic accidents are the major cause of maxillofacial trauma in our country and around the world. This has been proved by various studies in developing and developed countries. ${ }^{6}$ There is a paucity of studies which deal with maxillofacial injuries due to road traffic crashes alone. Most of the existing studies include maxillofacial injuries due to other causes - assaults, sports injuries, industrial accidents, fall from height, etc.

The male predominance in our study agrees with what is reported in the literature. ${ }^{1,6-9}$ The male to female ratio of 9:1 was comparable to other studies. ${ }^{10,11}$

Males are at a greater risk of crashes and maxillofacial injuries because of the increased use of vehicles and travel compared to females.

The mean age in our study was 32.08 years which was comparable to other studies. ${ }^{6,7,10}$ The peak incidence of maxillofacial injuries was in the age group 21 to 30 years which was in concordance with all the other studies. ${ }^{1,6-13}$ This is because of the increased use of vehicles and travel in the third decade of life.

The most common etiological factor for maxillofacial injuries is road traffic crashes in our country. This has been proved by several studies. ${ }^{6,7,11}$ Soft tissue injuries were the commonest type of maxillofacial injury throughout the literature. The incidence of soft tissue injuries in our study was $97 \%$, higher than in other studies. ${ }^{5,6}$

Plain radiographs were taken in all patients at the time of presentation and also for follow-up as was in our study. But plain radiographs suffer from inherent limitation of anatomical superimposition and soft tissue edema obscuring the fracture. ${ }^{14}$ Hwang et al evaluated 503 nasal bone fractures using lateral and Water's view, and only $82 \%$ of nasal bone fractures were identified. ${ }^{15}$

Computed tomography scan is the preferred imaging modality for multiple and complex maxillofacial injuries, it offers excellent bone details, especially in case of midface fractures which have a complex anatomy and also to evaluate associated head injury. ${ }^{15}$ Most of our patients were evaluated by axial sections of CT scan. Coronal sections were used in patients who are stable and with no cervical spine injury.

Maxilla fracture was the commonest fracture (58\%) of which majority were unilateral maxillary fractures $(45 \%)$, requiring no surgical intervention and anterior wall being commonly fractured $(57 \%)$. The incidence of complex fracture, Le Fort's was $13 \%$ of which Le Fort 2 was the commonest. Mandible is the commonest fractured bone in most of the other studies. This is because of the fact that most of these studies were retrospective studies on patients who had undergone intervention in the hospital and most of the studies included maxillofacial injuries due to various causes.

The second commonest bone fractured was the nasal bones $(43 \%)$. The incidence of nasal bone fractures was $11.1 \%$ in a prospective study of maxillofacial injuries due to various causes, the predominant cause of injury being road traffic crashes. ${ }^{3}$ Nasal bone fractures were classified into five types and their patterns studied and were comparable to other studies. ${ }^{12,16}$ Type I nasal bone fractures were the commonest in our study as against type II fractures in the above-mentioned studies. The disparity may be due to the fact that our study was a descriptive one, whereas the abovesaid studies were retrospective and the study population was on patients who required hospitalization and intervention. Type IV and V fractures were not that common in our study.

Twenty-six patients sustained frontal bone fractures in our study with anterior table (96\%) fractures being the commonest. Only one patient in our study had bitable fracture. In a study of 33 patients who suffered from frontal sinus fractures, $63 \%$ were anterior table fractures, $33 \%$ were bitable fractures and $3 \%$ were isolated posterior table fractures. ${ }^{17}$ Retrospective study of 875 frontal sinus fractures, the incidence of posterior table fracture was $7.7 \%$.Anterior table fractures being the most commonest type encountered. ${ }^{18}$ Isolated posterior table fractures although rare, are usually associated with intracranial complications like CSF rhinorrhea.

Orbital fractures were the third commonest fracture in our series $(41 \%)$. Lateral orbital wall fracture was the commonest type of orbital fractures $(61.8 \%)$. Various studies quote the medial orbital wall to be commonly involved. ${ }^{19}$ This variation may be due to the mode of injury sustained. The floor of the orbit was the least injured structure in our study.

Zygoma was fractured in 37\% cases, which included undisplaced (27\%) and displaced fractures (10\%). In studies by Obuekwe et al and Menon et al, the incidence of zygoma fractures were $18 \%$ and $31.7 \%$ respectively. ${ }^{13,20}$ Of the 37 fractures of the zygoma, arch fractures were the commonest (62.1\%). In a study by Adam et al, body of zygoma was commonly fractured (57.7\%) followed by combined fractures and isolated arch fractures. ${ }^{21}$

Le Fort fractures were present in 13\% cases, with Le Fort 2 being the commonest ( $7 \%$ ) which was in concordance with other studies, dealing with maxillofacial injuries predominantly caused by road traffic crashes. ${ }^{8,11}$

Among mandibular fractures, parasymphysis was the commonest site fractured (66\% of mandible fractures). These were compared to the fractures described in other studies. ${ }^{822,23}$ 
Head injury is the commonest associated injury in maxillofacial fractures. Multiple fractures were seen to be commonly associated with head injury. Of the 21 patients with head injury in our study, $19(90.4 \%)$ had multiple facial bone fractures. Hence, screening for head injury by $\mathrm{CT}$ scan becomes important in patients with multiple facial fractures.

Nasal packing and tracheostomy are the primary interventions that are done in the emergency room. Temporary IMF is done to stabilize the fractures. Closed reduction is advocated for nasal bone fractures. However, open reduction and internal fixation is the gold standard of treatment for maxillofacial fractures. It can be done using miniplate with screws, elevation and reduction procedures for zygoma fractures. Forty percent of our patients were managed by open reduction and internal fixation, $5 \%$ by closed reduction and IMF in $18 \%$ cases.

The overall complication rate in our study was around $11 \%$, that varied between 7 and $29 \%$ in various other studies. ${ }^{6}$ The studies vary in the incidence of complications, which can be explained by the differences in the patterns of fractures, the expertise available in the management. Studies quoting low incidence of complications have all emphasized the need for early intervention and stabilization of the fractures preferably with open reduction and internal fixation when appropriate.

In our study, malocclusion was the commonest complication encountered (8\%). Malocclusion is one of the commonest complication of maxillofacial fractures, the incidence of which is variable (19-53\%). ${ }^{6,7}$ Factors like, the type and location of fracture, patient factors, the expertize and availability of resources are all the determinants for developing malocclusion. ${ }^{7}$ Studies which quote a lesser incidence of malocclusion have accepted open reduction and internal fixation as a gold standard of treatment. ${ }^{9,24}$

Secondary wound infection was $4 \%$ in our study, comparable to the study by Ahmed et al (5.6\%) who also emphasized the need for prophylactic antibiotics. ${ }^{25}$ Studies by Zollen and Curry found a complication rate of $50.3 \%$ in patients not receiving antibiotic coverage compared to $6.25 \%$ complication rate in those who did. ${ }^{22}$

\section{CONCLUSION}

Fractures of the midfacial skeleton are the commonest encountered maxillofacial fracture in road traffic crashes and are almost always associated with varying types of soft tissue injuries. Clinical and radiological evaluation is required for early detection and adequate treatment of these fractures. Complications are commoner in these midfacial fractures. There is a large variability in the patterns of maxillofacial fractures due to a variety of contributing environmental, cultural and socioeconomic factors. Hence, further studies are warranted in this regard.

\section{REFERENCES}

1. Mohan D. IND-road accidents in India. IATSS Research 2009; 33:75-79.

2. Bali R, Sharma P, Garg A, Dhillion G. A comprehensive study on maxillofacial trauma conducted in Yamunanagar, India. J Inj Violence Res 2013;5:108-116.

3. Gopalakrishna G, Peek C, Kraus JF. Epidemiologic features of facial injuries among motorcyclists. Ann Emerg Med 1998; 32:425-430.

4. Denbergh BV, Karagozoglu KH, Heymans MW, Forouzanfar T. aetiology and incidence of maxillofacial trauma in Amsterdam: A retrospective analysis of 579 patients. J Craniomaxillofac Surg 2011;6:231-237.

5. Donald PJ, Sykes J. Facial fractures. In: Snow JB, Ballenger JJ, editors. Ballenger's Otorhinolaryngology Head and Neck Surgery.16th ed. BC Decker: Ontario; 2003. p. 900-950.

6. Chalya PL, Mchembe M, Mabula JB, Kanumba ES, Gilyoma JM. Etiological spectrum, injury characteristics and treatment outcome of maxillofacial injuries in a Tanzanian teaching hospital. J Trauma Manag Outcomes 2011;5:7-13.

7. Ozkaya O, Turgut G, Kayali MU, Ugurlu K, Kuran I, Bas L. A retrospective study on the epidemiology and treatment of maxillofacial fractures. Turkish J Trauma \& Emergency Surgery 2009; 15:262-266.

8. Subhashraj K, Nandakumar N, Ravindran C. Review of maxillofacial injuries in Chennai, India: a study of 2748 cases. Br J Oral Maxillofac Surg 2007;45:637-639.

9. Isik D, Gonullu H, Karadas S, Kocak OF, Keskin S, Garca MF, et al. Presence of accompanying head injury in patients with maxillofacial trauma. Turkish J Trauma \& Emergency Surgery 2012;18:200-206.

10. Kapoor P, Kalra N. A retrospective analysis of maxillofacial injuries in patients reporting to a tertiary care hospital in East Delhi. Int J Crtit Illn Inj Sci 2012;2:6-10.

11. Singh V, Malkunje L, Mohammad S, Singh N, Dhasmana S, Das SK. The maxillofacial injuries: a study. National J Maxillofacial Surgery 2012;3:166-171.

12. Ondik MP, Lipinski L, Dezfoli S, Fedok FG. The treatment of nasal fractures: a changing paradigm. Arch Facial Plast Surg 2009;11:296-302.

13. Menon S, Sinha R, Thapliyal G, Bandyopadhyay T. Management of zygomatic complex fractures in a tertiary hospital: a retrospective study. J Maxillofac Oral Surg 2011;10:138-141.

14. Som PM, Bradwein H, Sinonasal cavities: inflammatory disorders, tumours, fractures and post-operative findings. In: Som PM, Curtin HD, editors. Head and neck imaging. 3rd ed. Mosby: St Louis CV; 1996. p. 51-276.

15. Hwang K, Sunhye Y, Sun K. Analysis of nasal bone fractures: six year study of 503 patients. J Craniofacial Surg 2006; 7: 261-264.

16. Yilmaz MS, Guven M, Kayabasoglu G, Varli AF. Efficacy of closed reduction for nasal fractures in children. Br J Oral Maxillofac Surg 2013;4:33-38.

17. Gonty AA, Marciani RD, Adornato DC. Management of frontal sinus fractures: a review of 33 cases. J Oral Maxillofac Surg 1999;57:372-379. 
18. Choi M, Li Y, Shapiro SA, Havlik RJ, Flores RL. A 10year review of frontal sinus fractures: clinical outcomes of conservative management of posterior table fractures. Plast Reconstr Surg 2012;130:399-406.

19. Kim SH, Lee SH, Cho PD. Analysis of 809 facial bone fractures in a pediatric and adolescent population. Arch Plast Surg 2012; 39:606-611.

20. Obuekwea ON, Etetafiaa M. Associated injuries in patients with maxillofacial trauma. Analysis of 312 consecutive cases due to road traffic accidents. J Biomed Sci 2004;3:30-36.

21. Adam AAD, Zhi L, Bing LZ, Zhong Xing WU. Evaluation of treatment of zygomatic bone and zygomatic arch fractures: a retrospective study of 10 years. J Maxillofac Oral Surg 2012;11: 171-176.
22. Andreas ZJ, Benoit S, Olivier L, Nikola S, Hanna T, Tateyuki I. Incidence, aetiology and pattern of mandibular fractures in central Switzerland. Swiss Med Wkly 2011;141:132-137.

23. Natu SS, Pradhan H, Gupta H, Alam S, Gupta S, Pradhan R, et al. An epidemiological study on pattern and incidence of mandibular fractures. Plast Surg Int 2012;12:834-838.

24. Brasileiro BF, Passeri LA. Epidemiological analysis of maxillofacial fractures in Brazil: a 5-year prospective study. Oral Surg Oral Med Oral Pathol Oral Radiol Endod 2006;102: 28-34.

25. Ahmed HEA, Jaber MA, Fanas SHA, Karas M. The pattern of maxillofacial fractures in Sharjah, United Arab Emirates: a review of 230 cases. Oral Surg Oral Med Oral Pathol Oral Radiol Endod 2004;98:166-170. 